\title{
Effects of Blending Ethanol with Gasoline on the Performance of Motorcycle Catalysts and Airborne Pollutant Emissions
}

\author{
Jiun-Horng Tsai ${ }^{1,2}$, Ya-Li Ko ${ }^{1}$, Ci-Min Huang1, Hung-Lung Chiang ${ }^{3 *}$ \\ ${ }^{1}$ Department of Environmental Engineering, National Cheng Kung University, Tainan 70101, Taiwan \\ ${ }^{2}$ Research Center for Climate Change and Environment Quality, National Cheng Kung University, Tainan 70101, Taiwan \\ ${ }^{3}$ Department of Safety Health and Environmental Engineering, National Yunlin University of Science and Technology, \\ Yunlin 64002, Taiwan
}

\begin{abstract}
This study investigated the effects of blending ethanol with gasoline on the exhaust emissions of fuel-injected motorcycles. Regulated gasoline (RF), and 15 (E15) and 30 (E30) vol\% ethanol fuel were used as test fuels. Measurements of several air pollutants $\left(\mathrm{CO}, \mathrm{HC}\right.$, and $\left.\mathrm{NO}_{x}\right)$ and organic air pollutant groups were conducted for two new fuel-injected four-stroke motorcycles. In addition, various catalysts were inserted into the motorcycles' tailpipes to determine the characteristics and performance of the catalysts in treating the exhaust.

Compared to using RF, we found that using blended fuel potentially reduced the $\mathrm{CO}$ and $\mathrm{HC}$ emissions by $30-37 \%$ and $19-28 \%$, respectively. New catalytic systems, in conjunction with using different fuels, reduced $\mathrm{CO}, \mathrm{HC}$, and $\mathrm{NO}_{x}$ emissions in the tailpipe exhaust by $12-61 \%, 32-39 \%$, and $81-85 \%$, respectively. The CO and $\mathrm{HC}$ emissions were directly proportional in quantity to the running mileage of the catalyst, but the $\mathrm{NO}_{x}$ emissions were unaffected by this mileage, although they increased as the catalyst aged.

We also discovered that at identical running mileages for a catalyst, the fuel consumption increased by $-1.7-6.5 \%$ and 4.1-15\% when using E15 and E30 fuel instead of RF. Furthermore, the specific surface area and pore volume of the catalyst decreased with the aged catalyst the phosphorus and sulfur content in the catalyst increased with the catalyst's running mileage; adding ethanol to the fuel decreased emissions of paraffins, olefins, and aromatics but increased those of carbonyls; and the ozone formation potential of volatile organic compounds (VOCs) in the tailpipe exhaust was 16.7-17.2\% for paraffins, $22-33 \%$ for olefins, $26-45 \%$ for aromatics, and $4.9-25 \%$ for carbonyls.
\end{abstract}

Keywords: Criteria air pollutant; Fuel consumption; VOC species; Catalyst.

\section{INTRODUCTION}

Because of the depletion of fossil fuels, searching for alternative fuels has become essential. Transportation is a major fraction of global energy consumption with an energy demand of around 25-27\% (Conti et al., 2016; World Energy Council, 2016). This demand is increasing by $1.4 \%$ annually (U.S. EIA, 2016a). In the transportation sector, 90\% of greenhouse gas is being emitted by the use of gasoline and diesel fuels in the United States (U.S. EPA, 2019). The developing countries are contributing to $94 \%$ of the growth in the transportation energy sector (de Assis Brasil Weber et al., 2019). World transport energy consumption is set to reach 3906 Mtoe in 2040 (U.S. EIA, 2016a). In places where

\footnotetext{
* Corresponding author.

E-mail address: hlchiang@yuntech.edu.tw
}

traffic is busy and intensively crowded or in urban areas, motorcycles are much more convenient and flexible (Durant et al., 1996; Durant et al., 1999; Lin et al., 2019). Normally, the number of motorcycles around the world is approximately 350 million and increases with rises in the global metropolitan population (Chiang et al., 2014; Alves et al., 2015; Chernyshev et al., 2018). In terms of the global distribution of motorcycles, Asia is in the lead, followed by Europe, Latin America, North America and Africa (DeMarini et al., 2004; Costagliola et al., 2014, 2016). Motorcycles are very suitable for Asia, particularly in Asia's developing countries because of their lower operating costs, lower rates of fuel consumption and higher convenience. In Vietnam, India, Indonesia, Thailand and China, motorcycles account for more than $60 \%$ of the number of passenger vehicles in use (Weiss et al., 2015). Motorcycles are clearly a very important component of the transportation infrastructure in southern Asia.

Because of the inherent physicochemical characteristics of ethanol and isobutanol, it is possible for these fuels to 
spark ignition in an engine. This makes it possible to blend them with pure gasoline to reduce the dependency on petroleum fuels. The United States government is pushing ethanol fuel, and lately allowed the sale of E15 gasoline together with the long-approved E10 gasoline. A $10 \mathrm{vol} \%$ of anhydrous ethanol mixed with gasoline is widely used, without any need for engine modification, in almost all lightduty vehicles engines in the United States (U.S. EIA, 2016b). A higher ethanol blending such as $20-25 \%$ has been widely used in Brazil since the late 1970s after the 1973 oil crisis and an E85 blend is commonly used in the United States and Europe for flex-fuel vehicles (FFVs) (Rico, 2008; Larsen et al., 2009). E100 has been introduced in Brazil for neat gasoline vehicles and most recently for E100 FFVs. This shows that ethanol can be an important alternative fuel for gasoline.

Due to fuel consumption, the transportation sector makes a significant contribution to air pollution and global warming (Clairotte et al., 2013). The European Union (EU)'s Directive $2009 / 28 / \mathrm{EC}$ requires $10 \%$ of transport fuels to come from renewable energy by 2020 and this percentage will be increased in the following years (Clairotte et al., 2013; Rodriguez et al., 2015). Following the EU directive, the United States Environmental Protection Agency (U.S. EPA) has also set a target of 36 billion gallons of renewable fuel to be blended with gasoline by 2022 (Clairotte et al., 2013).

Normally, ethanol contains less energy than gasoline, hence, motor vehicles using ethanol fuel have lower fuel economy. At the same time, the addition of ethanol fuel increase acetaldehyde and nitrogen oxide emissions and have a significant impact on air quality, especially in the photochemical components of air pollution and in ozone formation (Sarkar et al., 2017; Kim et al., 2018; Tsai et al., 2018; Meng, 2019). Some researchers have investigated the torque, brake power and brake thermal efficiency of engines using an E20 ethanol/gasoline blend. Lower carbon monoxide and hydrocarbon emissions were determined for exhaust emissions from ethanol blending vehicles (Yao et al., 2018; Yusoff et al., 2018). $\mathrm{NO}_{x}$ emission change was generally insignificant (Yusoff et al., 2018), but high speeds and torque could produce high $\mathrm{NO}_{x}$. Hoang et al. (2019) found that when using E10 in the motorcycles which they tested there was a slight increase in engine power, and in $\mathrm{NO}_{x}$ and $\mathrm{CO}_{2}$ emissions, while $\mathrm{CO}$ and $\mathrm{HC}$ emissions were lowered. When a wide-open throttle test was conducted under steadystate conditions using E30, vehicle power decreased by $10 \%$ and fuel consumption increased by $5 \%$ in comparison with E0 (no ethanol addition gasoline), because of the lower heating value of E30 (Sakthivela et al., 2019). When E30 is used instead of $\mathrm{E} 0, \mathrm{NO}_{x}$ emissions increased by around 2.5 times, $\mathrm{CO}$ emissions decreased by $75 \%$ and $\mathrm{HC}$ emissions decreased by $66 \%$ (Sakthivela et al., 2019). A clear trend of reduced hydrocarbons and $\mathrm{CO}$ emissions and increased $\mathrm{NO}_{x}$ emissions have been observed as the ethanol concentration in fuel increased from $0 \%$ to $20 \%$ (Agarwal, 2007).

The huge number of motorcycles in developing countries presents many challenges, such as safety issues, increasing fuel prices and air pollution. Although motorcycles have lower fuel consumption per individual relative to four-wheel passenger cars due to their smaller engine capacity and lighter weight, motorcycles emit more pollutants per driving mileage (known as their emission factor), since the combustion of motorcycle engines is usually incomplete, and what is worse, they have poorer emission control/aftertreatment technologies. Vasic and Weilenmann (2006) observed that the ratios of mean emissions in $\mathrm{g} \mathrm{km}^{-1}$ from motorcycles and cars are very high, especially for $\mathrm{HC}$ in urban driving (factor of 222). When emissions were measured in terms of fuelbased emission factors $\left(\mathrm{g} \mathrm{L}^{-1}\right)$, the fuel-based emission factors of LDMCs (light-duty motorcycles) and HDMCs (heavyduty motorcycles) registered in or after the year 2000 were about 120 times higher than those of LDGVs (light-duty gasoline vehicles) in the same age group. In fact, the emission standards for motorcycles are 2-3 stages behind the emission standards applied to passenger cars (Sun et al., 2016). Therefore, motorcycles exhaust emissions cannot be ignored in any examination of total motor vehicle emissions. When ethanol (EA), methyl tertiary-butyl ether (MTBE) and ethyl tertiary butyl ether (ETBE) percentages are increased, $\mathrm{CO}$ and NMHC concentration decreases. The emission of $\mathrm{CO}$ decreases by $0.363,0.266$ and $0.356 \mathrm{~g} \mathrm{~km}^{-1}$ for light-duty vehicle when EA, MTBE and ETBE oxygenate blending ratios are increased (Lim et al., 2019). When Euro III motorcycles are equipped with catalyst and electronic fuel injection systems the $\mathrm{CO}$ and hydrocarbons in their emissions can be significantly reduced in comparison with Euro I and II carbureted motorcycles (de Assis Brasil Weber et al., 2019). There are certain potential hazards and unwanted side effects when using E10 fuel in a motorcycle. They will consume more fuel, especially if E85 is used. The ethanol industry states that engines that use E85 experience $25-30 \%$ less fuel power than they would be using regular gasoline. This is because ethanol contains less energy than gasoline despite having a higher natural octane number. Ethanol also is not effective in breaking up sludge in fuel tanks, which can lead to problems with clogged lines and filters as well as blocked carburetor jets and fuel injectors.

This study investigated the effects on exhaust emissions of ethanol blending in gasoline for fuel-injected motorcycles. Varied ethanol contents in gasoline, including $15 \mathrm{vol} \%$ and 30 vol\% ethanol blends, were conducted as test fuels. Criteria air pollutants $\left(\mathrm{CO}, \mathrm{HC}\right.$, and $\left.\mathrm{NO}_{x}\right)$, and organic air pollutant groups were identified using two new fuel-injected four-stroke motorcycles with $125 \mathrm{~cm}^{3}$ displacements. The exhaust propelled through various catalysts in the motorcycle tailpipes was analyzed at different mileages to determine its characteristics, as well as the overall performance of the engines. The results were then compared with the results from the same test motorcycles using different fuels (RF, E15 and E30).

\section{EXPERIMENTAL METHODS}

\section{Test Fuels and Motorcycle}

In this study gasoline was blended with $15 \%$ (E15) and $30 \%$ (E30) ethanol by volume. We prepared the regulated gasoline (95 octane commercial gasoline), E15 and E30 under the same octane number. The largest petroleum refinery in 
Taiwan (China Petroleum Corporation [CPC]) prepared the three types of gasoline used in this study. A commercial unleaded gasoline was used as the regulated gasoline (RF). This RF has an octane rating of 95. It includes a methyl tertbutyl ether (MTBE) oxygenating additive. By buying our fuel at a gasoline station operated by $\mathrm{CPC}$ we were able to get CPC to do composition analyses of the fuels, following American Society for Testing Materials procedures. The properties of the ethanol-blended gasolines and of the RF, measured by CPC, are presented in Table 1 . The motorcycles (SYM-GR 125) being tested in the experiment weighed about $112 \mathrm{~kg}$. Fuel injection was used as the fuel supply system. The engines were air cooled and used capacitive discharge ignitions in a single-cylinder arrangement. At their maximum power $(10 \mathrm{ps}$ at $8000 \mathrm{rpm})$, the compressor ratio of the engines was 8.6 and the maximum torque was $1.0 \mathrm{~kg}-\mathrm{m}$ at $5500 \mathrm{rpm}$. The emissions which resulted from using different ethanol-gasoline blends were compared to the emissions produced by an untuned non-catalyst motorcycle in order to highlight the effect which catalysts had on emissions.

The three-way catalytic system is a stainless steel container including a honeycomb monolith structure $(\varnothing 45 \mathrm{~mm} \times$ L $130 \mathrm{~mm}$ ) and catalytic converter. Alumina is employed as a high surface area support, the mixed oxides, $\mathrm{CeO}_{2}-\mathrm{ZrO}_{2}$ added as the $\mathrm{O}_{2}$ storage promoters, precious metals ( $\mathrm{Rh}, \mathrm{Pt}$ and $\mathrm{Pd}$ ) are the active phases for exhaust reactions and $\mathrm{BaO}$ and/or $\mathrm{La}_{2} \mathrm{O}_{3}$ act as stabilizers of the surface area of support (Kašpar et al., 2003). Catalyst system with different running mileage such as zero, $<500,5000,10,700$ and $16,200 \mathrm{~km}$ was presented as C-0, C- $<500, \mathrm{C}-5000, \mathrm{C}-10700$ and C16200 , respectively.

\section{Test Procedures}

Emission tests were executed using chassis dynamometers in the laboratory of a regional motorcycle manufacturer. The main system included a chassis dynamometer $(20 \mathrm{~kW}$; Meiden), a dilution tunnel, a constant volume sampler unit (CVS-51S; HORIBA), and an exhaust gas analyzer (MEXA-7200; HORIBA) for $\mathrm{CO}, \mathrm{HC}$ and $\mathrm{NO}_{x}$. Motorcycle details (registration number, maker, category, and test weight) were loaded into the dynamometer system to estimate the appropriate inertia loading for the motorcycle during the testing process. The motorcycle testing followed the WMTC (World Motorcycle Test Cycle) driving cycle. The temperature of the test room ranged from $20^{\circ} \mathrm{C}$ to $30^{\circ} \mathrm{C}$. The sampling equipment for organic air pollutants was similar to those we used in previous research (Tsai et al., 2003; Tsai et al., 2017). Following procedures recommended by the WMTC, a vacuum box containing a 10-L Tedlar bag was used to sample emissions. By setting a controlling flow rate of $150 \mathrm{~mL} \mathrm{~min}^{-1}$, exhaust gas was drawn in through a sampling pump. In order to direct samples into the sample bag, three-way control valves were used. Due to the limitations of the sampling equipment, the sampling work was performed by manual operation. Before doing each emission test, strict fuel change protocols were used to ensure minimal crossover between test fuels took place so as to ensure that all the tests were done consistently. The process of changing fuel was as follows: The fuel tank was drained, $1 \mathrm{~L}$ of the new fuel was added in, the engine was idled for $5 \mathrm{~min}$, the new test fuel was flushed through the fuel supply system thoroughly, and then the tank became empty again. For the remainder of the emission test, $2 \mathrm{~L}$ of the new fuel were then added. Next, the test motorcycle and fuel were conditioned taking the motorcycle out on the road for $10 \mathrm{~min}$ without measuring any emissions. Before the cold start testing process began, the motorcycle was parked at room temperature for more than $6 \mathrm{~h}$. The three kinds of tests taken were all directed at detecting organic compounds. Two tests used E15, E30, and one test used regulated gasoline (RF).

\section{Analytical Procedures}

The testing bags were collected and put into a black container after sampling and underwent a hydrocarbon species analysis in the laboratory within $24 \mathrm{~h}$. Using a purge and trap system (Varian), hydrocarbon species with a carbon number larger than 3 ( $>\mathrm{C} 3$ ) were preconcentrated. Using gas chromatography/mass spectrometry (GC/MS; Star 3600

Table 1. Properties of the test fuels(regulated gasoline, E15 and E30).

\begin{tabular}{llll}
\hline Parameter & Regulated gasoline (RF) & E15 & E30 \\
\hline RON & 95 & 95.1 & 94.9 \\
RVP (kPa) & 55.3 & 49.8 & 44.6 \\
Density (g mL ${ }^{-1}$ ) & 0.74 & 0.75 & 0.73 \\
Ethanol (wt\%) & - & 15.78 & 29.32 \\
Ethanol (vol\%) & - & 14.21 & 26.15 \\
Paraffins (vol\%) & 11.02 & 7.93 & 9.23 \\
Isoparaffins(vol\%) & 29.38 & 36.53 & 42.81 \\
Olefins (vol\%) & 10.10 & 10.50 & 9.05 \\
Naphthenes(vol\%) & 7.31 & 5.65 & 6.24 \\
Aromatics( vol\%) & 31.32 & 24.45 & 7.38 \\
Benzene (vol\%) & 0.62 & 0.43 & 0.25 \\
MTBE (vol\%) & 12.15 & - & - \\
Oxygen content (wt\%) & 1.98 & 5.85 & 11.32 \\
Heating value (kcal kg ${ }^{-1}$ ) & 10841 & 10158 & 9985 \\
Carbon (wt\%) & 83.96 & 81.71 & 75.63 \\
Hydrogen $(\mathrm{wt} \%)$ & 11.83 & 12.78 & 14.15 \\
\hline
\end{tabular}


GC plus a Saturn $2000 \mathrm{MS}$; Varian), the samples were quantified. Using liquid nitrogen, the temperature of the trap system was cooled down to $160^{\circ} \mathrm{C}$. In order to purge, the thermal desorber was then preheated to $200^{\circ} \mathrm{C}$. The $\mathrm{GC}$ was equipped with a fused silica capillary column $(60 \mathrm{~m} \mathrm{~L} \times$ $0.32 \mathrm{~mm}$ ID with $0.1 \mathrm{~mm}$ film thickness, DB-1) and connected to the MS. The certified standard gas (56 Environ-Mat Ozone Precursor; Matheson) was diluted with ultrahighpurity nitrogen $(99.995 \%)$ in dilution bottles to reach the calibration standards. For GC/MS, the R-squared $\left(r^{2}\right)$ of the calibration curves of the 56 VOC species were generally higher than 0.995 , the relative standard deviation (RSD) was less than $8 \%$. Commercially available cartridges filled with 2,4-dinitrophenylhydrazine (Supelco) were used to collect carbonyl components in the exhaust. In the laboratory, the cartridge was first extracted from an aliquot of $2 \mathrm{~mL}$ acetonitrile (Merck). The extraction procedure was repeated with $5 \mathrm{~mL}$ acetonitrile. The extraction solution was injected into a high-performance liquid chromatographer (HPLC; 1100 series; Hewlett Packard) equipped with an auto sampler (G1313A; Hewlett Packard) and an ultraviolet-visible detector (Hewlett Packard). A total of 15 carbonyl compounds were analyzed. Each carbonyl compound was quantified by its liquid standard calibration curve (Supelco). The $\mathrm{r}^{2}$ of the carbonyl calibration curves was $>0.9999$, the RSD was $<5 \%$, the accuracy ranged from $98 \pm 2.6 \%$ to $105 \pm 3.8 \%$, and the method detection limit ranged from 6.23 (acetone) to $165 \mathrm{mg} \mathrm{m}^{-3}$ (2,5-dimethylbenzaldehyde). Background samples (room air) were also collected in the dynamometer laboratory and deducted from the test results. The results revealed that the $\mathrm{VOC}$ concentration was $<125 \mathrm{mg} \mathrm{m}^{-3}$ (toluene), and the VOC concentration of the dynamometer laboratory could be ignored being $<10$ times that of the motorcycle exhaust.

\section{Ozone Formation Potential of VOC Species}

Generally, MIR is popular in identifying the ozone formation potential (OFP) in various VOC compounds. The equation is as follows (Russell et al., 1995):

$$
\operatorname{MIR}=\max \left\{\left[\partial\left(\mathrm{O}_{3}\right)_{\mathrm{p}} / \partial \mathrm{E}_{\mathrm{i}}\right]\right\}
$$

for all VOCs $/ \mathrm{NO}_{x}$, where $\left(\mathrm{O}_{3}\right)_{\mathrm{p}}$ is maximum ozone concentration, $\mathrm{E}_{\mathrm{i}}$ is incremental of VOC concentration. The VOC species motorcycle exhaust emission factors associated with the maximum incremental reactivity factors (Carter, 2009) were applied to determine the OFP (in $\mathrm{mg}-\mathrm{O}_{3}$ produced per $\mathrm{km}$ ) of the motorcycle exhaust.

\section{RESULTS AND DISCUSSION}

\section{Criteria Pollutants}

The study identified the following fuel effects: For regulated gasoline, the $\mathrm{CO}, \mathrm{HC}$, and $\mathrm{NO}_{x}$ emission was 3.4, 0.47 , and $0.37 \mathrm{~g} \mathrm{~km}^{-1}$, respectively, without catalyst treatment (shown as Fig. 1). When compared with regulated gasoline, E15 CO and HC emissions were reduced by $30 \%$ and $19 \%$, respectively. When compared with regulated gasoline, E30 $\mathrm{CO}$ and $\mathrm{HC}$ emission were reduced by up to $37 \%$ and $28 \%$, respectively. However, $\mathrm{NO}_{x}$ emission increased $8.1 \%$ for E15 and showed only a slight reduction $(2.7 \%)$ for E30. The $\mathrm{NO}_{x}$ emission trend seemed not to depend on the fraction of ethanol blended into the gasoline. Results indicated that gasoline blended with ethanol can reduce the $\mathrm{CO}$ and hydrocarbon emissions from tailpipe exhaust. The blending of ethanol in regular gasoline reduced $\mathrm{NO}_{x}$ using E30 and increased $\mathrm{NO}_{x}$ using E15. Ethanol blending increases the oxygen content in gasoline and the volatility of gasoline. As a result, ethanol blending can be an effective method for reducing $\mathrm{CO}$ and hydrocarbon emissions. However, the fact that blended gasoline burns at a lower temperature can lead to consequent NO formation. The hydroxyl functional groups present in the ethanol flame can reduce hydrocarbon production and lower NO formation (Bergthorson and Thomson, 2015). Some studies show conflicting results (i.e., an increase of $\mathrm{NO}_{x}$ with ethanol blending) (Najafi et al., 2009), illustrating the inherent complexity in these studies created by the wide flexibility in operating parameters and by engine specific complications. Research shows that reductions can reach up to $30 \%$ of $\mathrm{CO}$ emissions, depending on the type and age of an engine/vehicle, the emission control system used, and the atmospheric conditions in which the vehicle operates (Agarwal, 2007).

This study identified the following catalyst effects: For regulated gasoline, when a new catalyst was used, the $\mathrm{CO}$, $\mathrm{HC}$ and $\mathrm{NO}_{x}$ in emissions were reduced by $33 \%, 32 \%$, and $81 \%$ (respectively) when compared with a non-catalyst tailpipe exhaust system (shown as Fig. 1); for E15 fuel, the $\mathrm{CO}, \mathrm{HC}$ and $\mathrm{NO}_{x}$ emissions were reduced by $12 \%, 39 \%$, and $85 \%$ (respectively) when a new catalyst was used when compared to a non-catalyst system. For E30 fuel, the CO, $\mathrm{HC}$ and $\mathrm{NO}_{x}$ emissions was reduced by $61 \%, 38 \%$, and $81 \%$ (respectively) when using a new catalyst when compared to a non-catalyst system.

The study identified an aging effect: $\mathrm{CO}, \mathrm{HC}$ and $\mathrm{NO}_{x}$ emissions could increase from $6.1 \%$ to $25 \%, 9.4 \%$ to $25 \%$ and $14 \%$ to $43 \%$, respectively when the engines with catalysts were run from 5000 to $16,200 \mathrm{~km}$ on regulated gasoline (shown as Fig. 1); when engines with catalysts were run for 5000 to $16,200 \mathrm{~km}$ using $\mathrm{E} 15, \mathrm{CO}, \mathrm{HC}$ and $\mathrm{NO}_{x}$ emissions could increase from $5.3 \%$ to $12 \%, 13 \%$ to $52 \%$ and $33 \%$ to $83 \%$, respectively; and when engines with catalysts were run for the same distance using $\mathrm{E} 30, \mathrm{CO}, \mathrm{HC}$ and $\mathrm{NO}_{x}$ emissions could increase from $81 \%$ to $104 \%, 4.8 \%$ to $29 \%$ and $14 \%$ to $57 \%$, respectively. $\mathrm{CO}$ and $\mathrm{HC}$ emissions were directly proportional to the catalyst mileage. The running mileage of catalyst was between brand new and $16,200 \mathrm{~km}$; in this range, the increase of $\mathrm{CO}$ emission rate was 37.4, 14.9 and $50.0 \mathrm{mg}$ per $1000 \mathrm{~km}$, and that of $\mathrm{HC}$ emission rate was 4.59 , 7.38 and $3.88 \mathrm{mg}$ per $1000 \mathrm{~km}$ for RF, E15 and E30, respectively. However, the $\mathrm{NO}_{x}$ emission could increase after the catalyst aged, but the $\mathrm{NO}_{x}$ emission factor did not depend on the catalyst mileage.

The study acquired the following data related to fuel consumption. The fuel consumption of motorcycles with tailpipes without catalyst systems was $24.16 \mathrm{~mL} \mathrm{~km}^{-1}$ for regulated gasoline, $25.19 \mathrm{~mL} \mathrm{~km}^{-1}$ for E15, and $25.91 \mathrm{~mL} \mathrm{~km}^{-1}$ for E30. There was an increase of $7.2-10.5 \%$ in fuel 


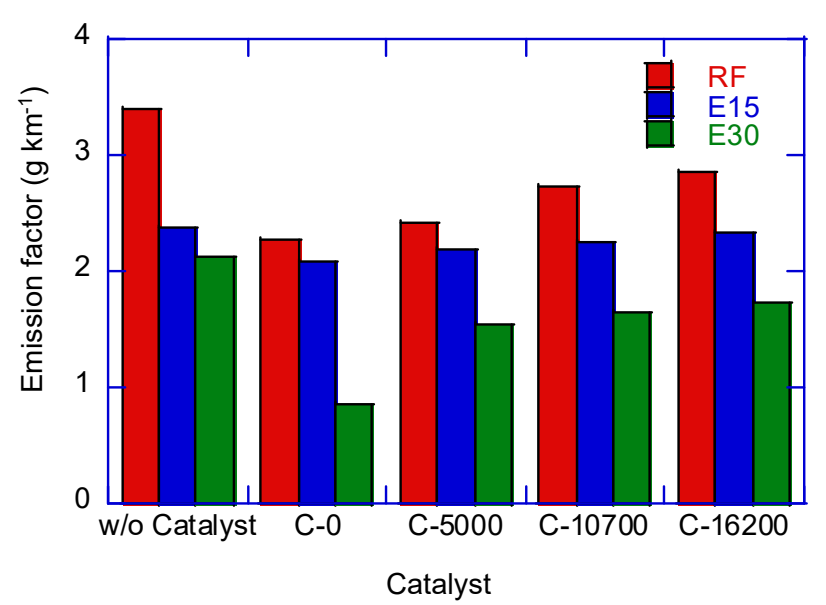

(a) $\mathrm{CO}$

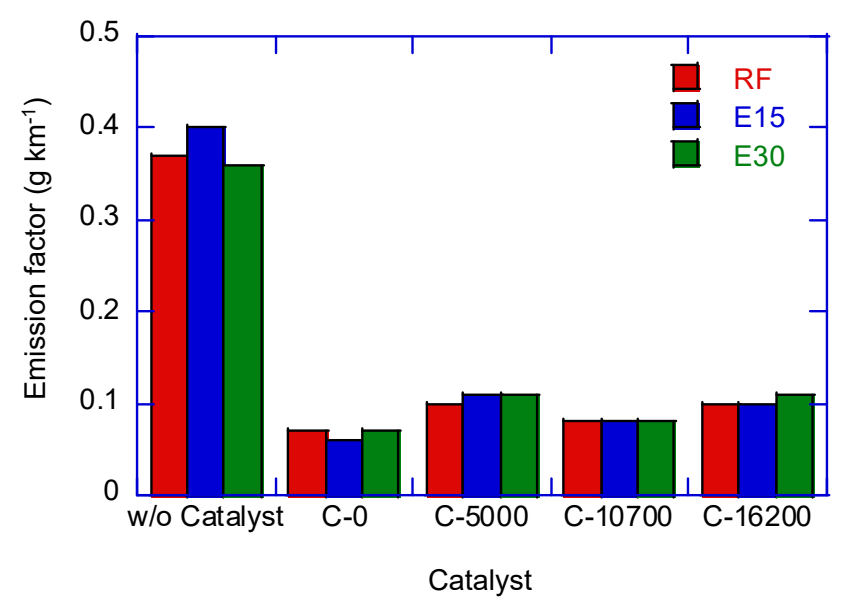

(c) $\mathrm{NO}_{\mathrm{x}}$

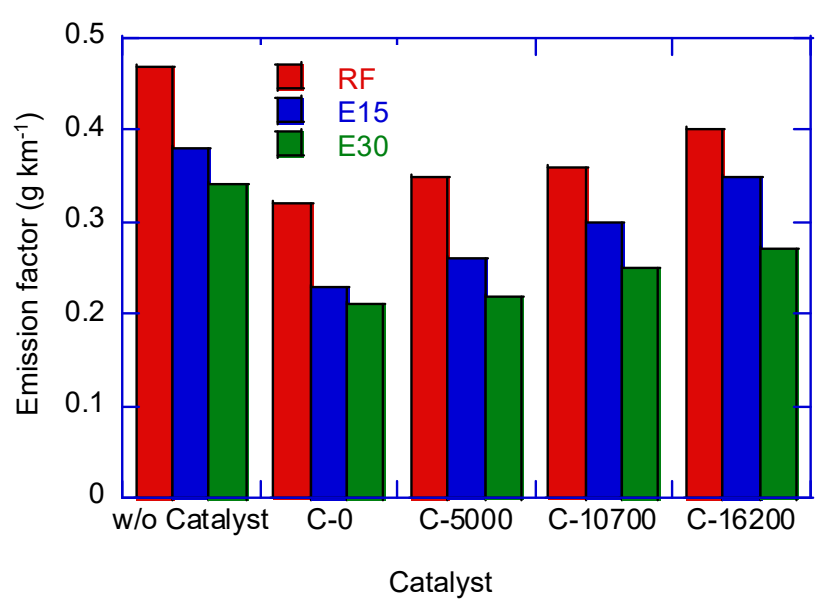

(b) $\mathrm{HC}$

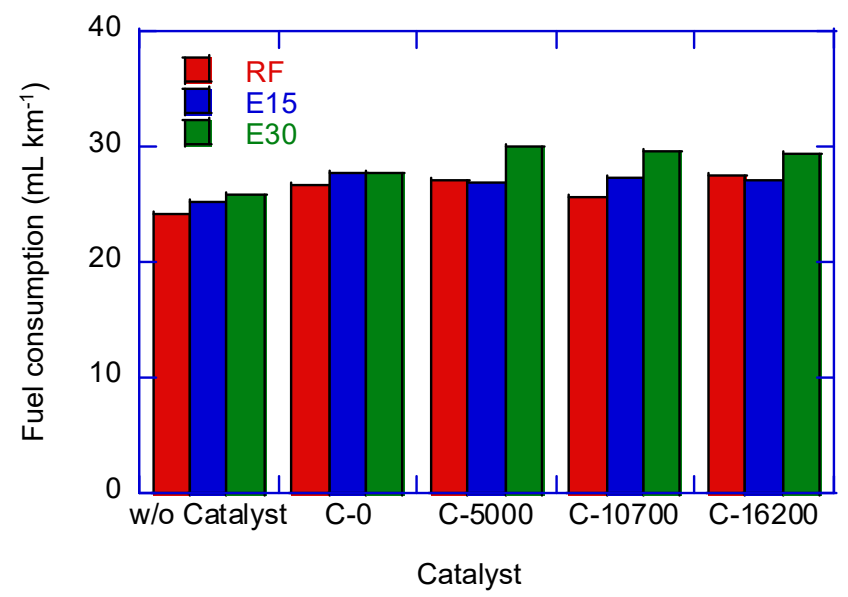

(d) Fuel consumption

Fig. 1. $\mathrm{CO}, \mathrm{HC}, \mathrm{NO}_{\mathrm{x}}$ emission and fuel consumption for different ethanol blending fuel of motorcycles without catalyst or with catalyst. (running mileage: 0, 5000, 10700 and $16200 \mathrm{~km}$ ).

consumption when motorcycles had catalysts as compared to those that did not have catalyst systems.

The performance of fuel consumption could range from -3.6 to $3.0 \%$ for regulated gasoline, from -3.5 to $-1.5 \%$ for E15, and from 5.6 to $7.9 \%$ for E30 in the catalyst mileage range of 5000 to $16,200 \mathrm{~km}$. For the same catalyst mileage, the fuel consumption could be $-1.7-6.5 \%$ different between E15 and regulated gasoline. Fuel consumption could increase $4.1-15 \%$ for E30 in comparison with the regulated gasoline. High ethanol addition in gasoline could increase fuel consumption due to the low energy content of ethanol in comparison with the gasoline.

Because ethanol has a high octane rating, the addition of ethanol to gasoline can lead to a reduction in the aromatic HCs (such as benzene), and other hazardous high-octane additives commonly used to replace tetraethyl lead in gasoline (Taylor et al., 1996). The addition of ethanol can enhance the volatility of gasoline. However, some studies have identified divergent results about $\mathrm{NO}_{x}$ emissions, showing the ethanol concentration in the fuel increased anywhere from $0 \%$ to $20 \%$. So, while the addition of ethanol can reduce $\mathrm{CO}$ and $\mathrm{HC}$, aldehydes and unburned ethanol emissions, and decrease or increase $\mathrm{NO}_{x}$, results can vary depending on operating conditions, spark advance timing and other parameters (de Melo et al., 2012).

\section{Catalyst Characteristics}

Fig. 2 shows the nitrogen adsorption-desorption isotherms and reveals representative Type IV isotherms with H2-type hysteresis for catalysts (Bumajdad et al., 2006). Results indicated that mesoporous structures with ink-bottle type pores (Lan et al., 2014), and the addition of noble metals, could have an effect on the pore types of the catalyst supporting materials. At lower relative pressure $\left(\mathrm{P} / \mathrm{P}_{0}<0.6\right)$, monolayer nitrogen adsorption occurs on the walls of the mesopores. As the relative pressure rises, the isotherms exhibit capillary condensation at a relative pressure around 0.8 . If higher relative pressures occur, multilayer adsorption occurs for catalyst support. For catalyst-5000, catalyst10700 and catalyst-16200, the hysteresis loop observed was insignificant, revealing a blocking effect due to the formation of soot particles, and the ink-bottle-shaped pores became blocked. The specific surface areas of catalyst-5000 and catalyst- 16200 decreased by $40-50 \%$ and $60-70 \%$, respectively, of the catalyst materials (shown as Table 2). Moreover, the pore diameter increased significantly from 


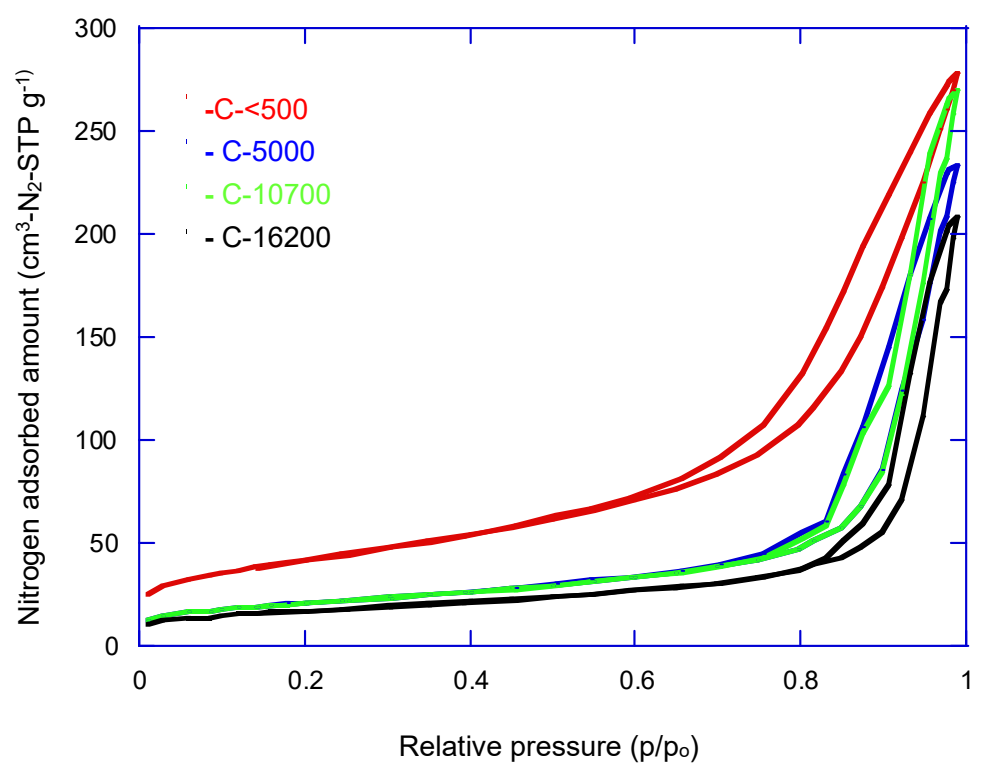

Fig. 2. Nitrogen adsorption and desorption isotherms for catalyst under different running mileage (mileage: $<500,5000$, 10700 and $16200 \mathrm{~km})$.

Table 2. Specific surface area, pore volume and average pore diameter of catalyst.

\begin{tabular}{llll}
\hline Catalyst running mileage $(\mathrm{km})$ & $\mathrm{BET}\left(\mathrm{m}^{2} \mathrm{~g}^{-1}\right)$ & $\mathrm{PV}\left(\mathrm{cm}^{3} \mathrm{~g}^{-1}\right)$ & $\mathrm{PD}(\AA)$ \\
\hline$<500$ & $163 \pm 25$ & $0.434 \pm 0.065$ & $113 \pm 10$ \\
500 & $92.0 \pm 35$ & $0.362 \pm 0.024$ & $193 \pm 36$ \\
10700 & $78.6 \pm 13$ & $0.354 \pm 0.015$ & $225 \pm 41$ \\
16200 & $62.3 \pm 15$ & $0.346 \pm 0.051$ & $263 \pm 21$ \\
\hline
\end{tabular}

BET: Specific surface area, PV: pore volume and PD: average pore diameter.

$113 \AA$ (new catalyst) to $193 \AA$ (catalyst-5000) and $263 \AA$ (catalyst-16200). Total pore volumes of aging catalysts were reduced by $83 \%$ and $80 \%$ when compared to brand new catalysts (shown as Table 2 ). Incompletely consumed products (such as soot particles) were transported into the pores of the catalyst to decrease the specific surface area and pore volume. The catalyst supports, and noble metal particles, maintained a stable textural structure during the exhaust treatment and application of high temperatures. However, under certain conditions the noble metals could be transported into the inner pore and deposited on the wall of the pore, with the result that the pore became blocked by the noble metals, reducing pore volume and specific surface area, and the pore structures collapsed completely due to the encapsulation of noble metal particles (Monte and Kašpar, 2005).

In this study the element constituents of the catalyst were Al (19.5-22.3\%), Ce (4.0-5.5\%), Ni (4.5-5.5\%), Fe (1.4$3.3 \%), \mathrm{Zr}(1.2-1.8 \%)$, La (1.0-1.5\%), Ca (0.10-0.36\%) and $\mathrm{Zn}(0.008-0.216 \%)$ (shown as Fig. 3(a)). Three catalytic noble metals were determined to exist in the catalyst. These were $\mathrm{Rh}(1.0-1.5 \%), \mathrm{Pd}(1.3-1.9 \%)$, and Pt (1.3-1.8\%) (shown as Fig. 3(b)). Results indicated that the noble metals became reduced after the mileage increased. Some toxic elements were analyzed such as P (0.005-1.472\%), and S (0.03-0.94\%) (shown as Fig. 3(b)).

Some research has indicated that alkaline earth metals $(\mathrm{Ca}$ and Sr etc.) (Fernández-García et al., 2002; Swatsitang et al., 2016), rare earth metals (Y, La, Pr, Nd, and Sm etc.) (Tan et al., 2015; Tan et al., 2016) and transition earth metals (Cr, $\mathrm{Mn}, \mathrm{Fe}, \mathrm{Co}, \mathrm{Ni}$, and $\mathrm{Cu}$ etc.) can enhance thermal stability due to the electropositive promoters which they introduce into the lattice of solid solutions in catalysts (Li et al., 2010; Alla et al., 2017). Phosphate compounds such as phosphate esters, thiophosphate esters, metal thiophosphates and phosphorus-containing ionic liquids can be used as lubricant additives in antiwear or extreme pressure additives (Johnson, 2016). Phosphate additives can serve as a protective film and reduce friction in bearing material systems (Johnson, 2016). This may be the main reason for $\mathrm{P}$ accumulation in the catalyst system after an increase of running mileage.

This study determined that the materials used in the catalyst were these: $\mathrm{Al}_{2} \mathrm{O}_{3}$ was the support used to react with a $\mathrm{CeO}_{2}-\mathrm{ZrO}_{2}$ solid solution to form alumina-ceria-zirconia complex oxide that has high thermal stability and reducibility (Acuña et al., 2014; Piumetti et al., 2016); catalytic novel metals, including $\mathrm{Pt}, \mathrm{Pd}$ and $\mathrm{Rh}$, were used to treat the exhaust because they can convert any incomplete combustion of $\mathrm{CO}$ and $\mathrm{HC}$ into $\mathrm{CO}_{2}$ and $\mathrm{H}_{2} \mathrm{O}$. Rh was identified. It enhances the $\mathrm{CO}, \mathrm{H}_{2}$, and $\mathrm{NO}$ reactants to form $\mathrm{CO}_{2}, \mathrm{H}_{2} \mathrm{O}$, and $\mathrm{N}_{2}$ over the catalyst composite materials. $\mathrm{Rh}$ can dissociate NO better than Pt and Pd (Shelef and Graham, 1994). The $\mathrm{Ce}_{2} \mathrm{O}_{3}$ was used to capture excess $\mathrm{O}_{2}$ to form $\mathrm{CeO}_{2}$ for $\mathrm{CO}$ oxidation and this mechanism also enhanced the $\mathrm{NO}$ reduction to form $\mathrm{N}_{2}$ (Ramanathan and Sharma, 2011). 


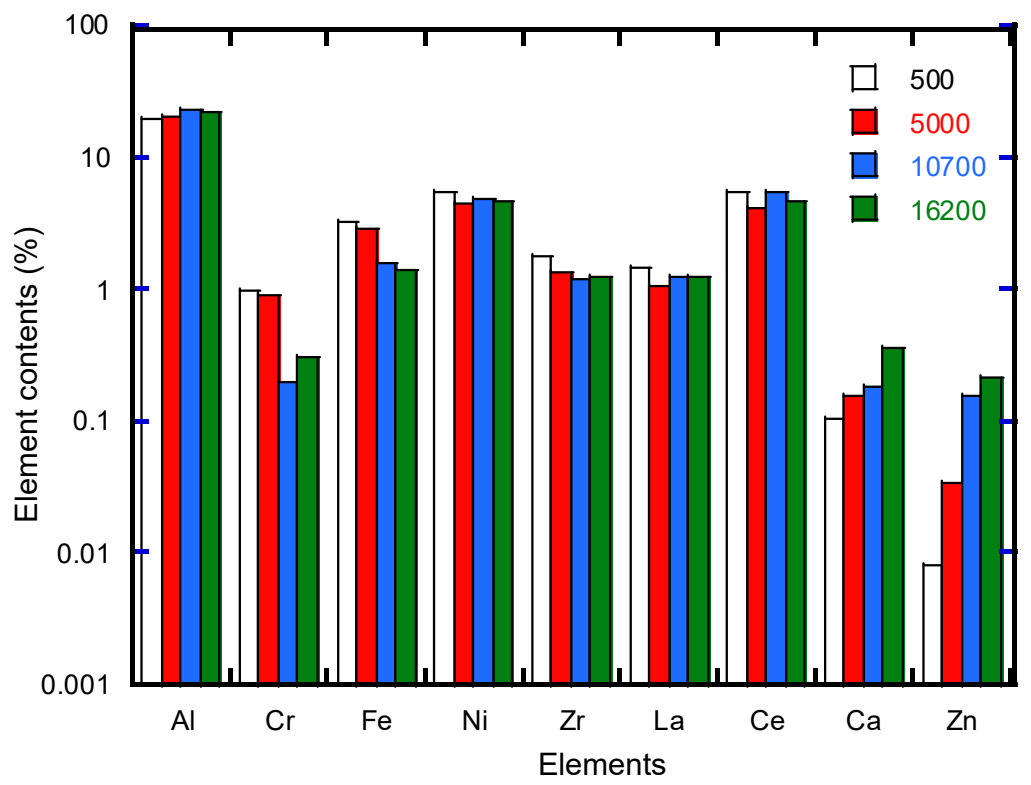

(a) Support and catalyst elements

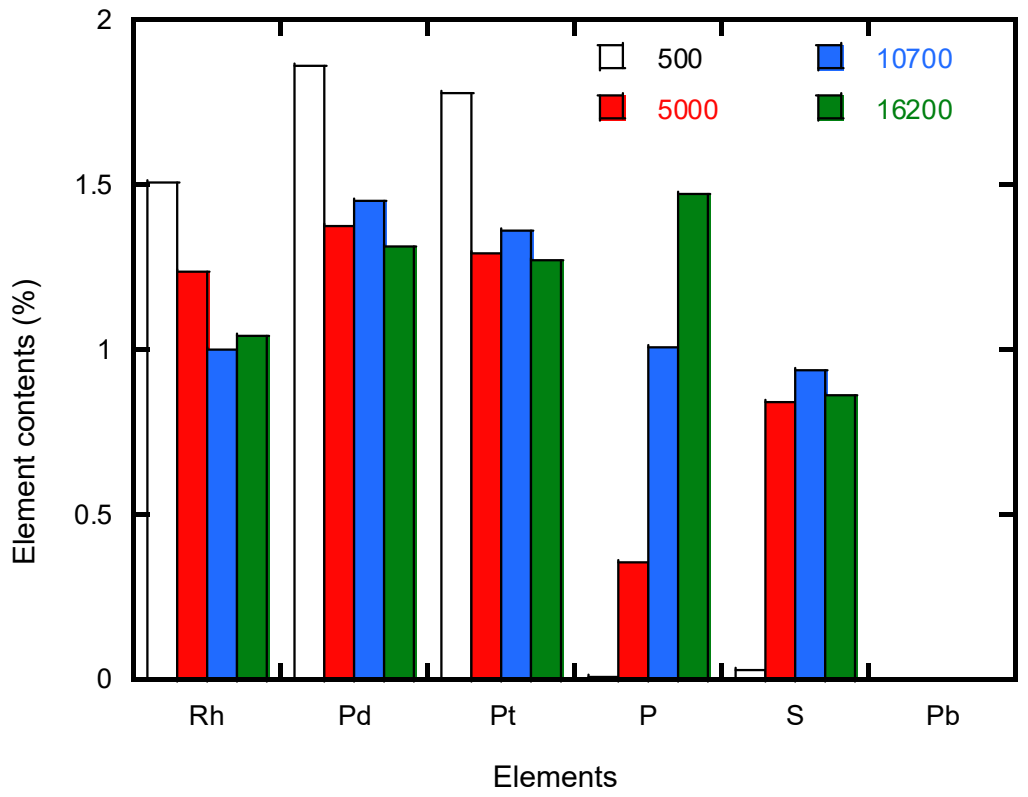

(b) Nobel and poisoning elements

Fig. 3. $\mathrm{CO}, \mathrm{HC}, \mathrm{NO}_{\mathrm{x}}$ emission and fuel consumption for different ethanol blending fuel of motorcycles with various running mileage of catalyst system (mileage: $<500,5000,10700$ and $16200 \mathrm{~km}$ ).

\section{VOCs Characteristics}

In this study an analysis of the VOC species was conducted. The major species of paraffins identified included isopentane, methyl hexane, 2,3-dimethylbutane, $n$-heptane, and cyclopentane, 1-butene, isoprene, and 1-hexene. These were the main olefin species. For aromatic species, toluene, benzene, xylene, ethylbenzene, 1,3,5-trimethylbenzene and ethyltoluene were found to be highly abundant in the exhaust. For carbonyls, the main species were acetaldehyde, acetone, formaldehyde, and benzaldehyde. For non-catalysts in the tailpipe, the analyzed VOCs emission factor was $116 \mathrm{mg} \mathrm{km}^{-1}$ for regulated gasoline, $76.8 \mathrm{mg} \mathrm{km}^{-1}$ for E15 and $51.5 \mathrm{mg} \mathrm{km}^{-1}$ for E30. The VOC group fraction was 49
$52 \%$ paraffins, $9.5-14 \%$ olefins, $26-30 \%$ aromatics and $4.5-16 \%$ carbonyls in the tailpipe exhaust (shown as Fig. 4). The addition of ethanol reduced paraffins, olefins and aromatics emissions and increased the carbonyls emission. After the catalyst treatment the VOCs exhaust was reduced from 116 to $63.1 \mathrm{mg} \mathrm{km}^{-1}$ (a $45.6 \%$ reduction) for regulated gasoline, from 76.8 to $40.5 \mathrm{mg} \mathrm{km}^{-1}$ (a $47.3 \%$ reduction) for E15 and from 51.5 to $25.5 \mathrm{mg} \mathrm{km}^{-1}$ (a $50.5 \%$ reduction) for E30. VOC emissions increased as catalyst mileage increased from 0 to $16,200 \mathrm{~km}$. These VOC emissions increases were from 63 to $99 \mathrm{mg} \mathrm{km}^{-1}$ for regulated gasoline, from 40 to $68 \mathrm{mg} \mathrm{km}^{-1}$ for E15 and from 26 to $41 \mathrm{mg} \mathrm{km}^{-1}$ for E30 (shown as Fig. 6(a)). 


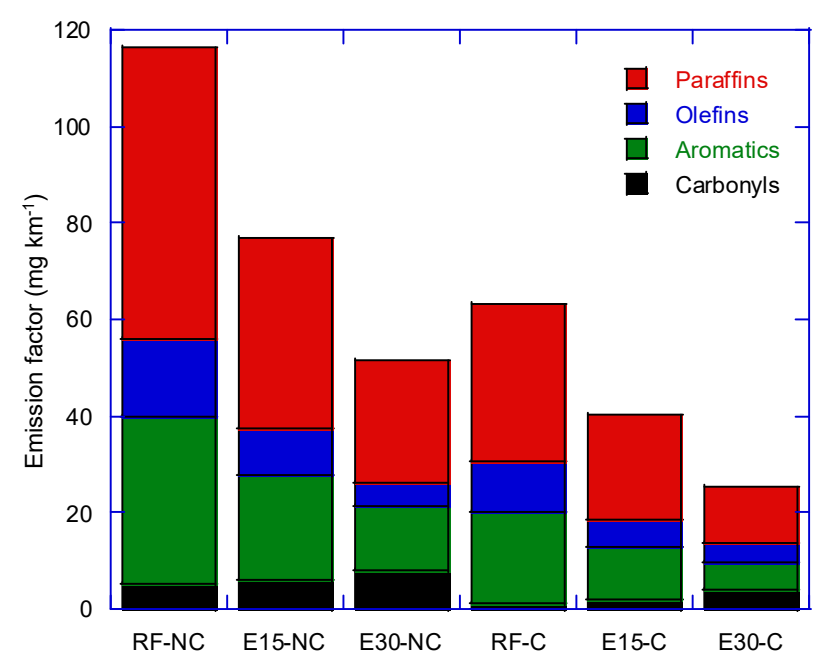

Fig. 4. VOCs emission factors for regulated gasoline (RF), E15 and E30 associated with non-catalyst (NC) and catalyst (C).

\section{Ozone Formation Potential}

VOCs are the important precursors in $\mathrm{O}_{3}$ formation (Alvim et al., 2018; Deng et al., 2018; Jia et al., 2018; Meng et al., 2019) and most of them are the hazardous air pollutants (HAPs) (Widiana et al., 2017; Hua et al., 2018). For the olefin paraffin species, the major components with potential for ozone formation included isopentane, cyclopentane and 2-methylpentane, 1-butene, isoprene, 1-hexene and trans-2pentene. For the aromatic species, xylene, toluene, 1,3,5trimethylbenzene, 1,2,4-trimethylbenzene, and ethyltoluene were shown to be highly abundant. For carbonyls, the main ozone formation potential species were acetaldehyde, and formaldehyde. When there was no catalyst in the tailpipe, the analyzed VOCs ozone formation potential was $457 \mathrm{mg}$ $\mathrm{O}_{3} \mathrm{~km}^{-1}$ for regulated gasoline, $298 \mathrm{mg}-\mathrm{O}_{3} \mathrm{~km}^{-1}$ for $\mathrm{E} 15$ and $196 \mathrm{mg}_{-} \mathrm{O}_{3} \mathrm{~km}^{-1}$ for E30. The fractions of VOC materials with ozone formation potential in the tailpipe exhaust were $16.7-17.2 \%$ paraffins, $22-33 \%$ olefins, $26-45 \%$ aromatics and $4.9-25 \%$ carbonyls (shown as Fig. 5). The addition of ethanol was shown to reduce paraffins, olefins and aromatics emissions and to increase the carbonyls emission. When the exhaust was treated using a catalyst system, the ozone formation potential of analyzed VOCs was reduced from 457 to $256 \mathrm{mg}_{-} \mathrm{O}_{3} \mathrm{~km}^{-1}$ (a $44.0 \%$ reduction) for regulated

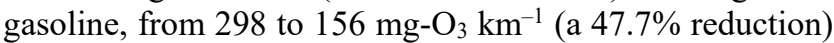

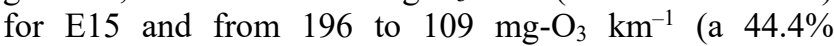
reduction) for $\mathrm{E} 30$. As the catalyst mileage increased from 0 to $16,200 \mathrm{~km}$, the ozone formation potential of VOCs increased from 256 to $407 \mathrm{mg}-\mathrm{O}_{3} \mathrm{~km}^{-1}$ for regulated

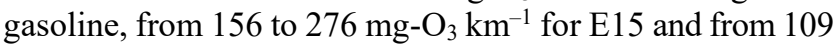
to $183 \mathrm{mg}-\mathrm{O}_{3} \mathrm{~km}^{-1}$ for E30 (shown as Fig. 6(b)).

The potential strategy of emission reduction of motorcycle suggests the power supplied by the electricity or low airborne emission fuels, and improving the infrastructure of the transportation to eliminate the application of motorcycle.

In Taiwan, the 3\% ethanol addition into gasoline as E3, it could be sold about $7834 \mathrm{~kL}$ in 2013 . The E3 gasoline was executed in 2007, however, the fraction of E3 sales volumes

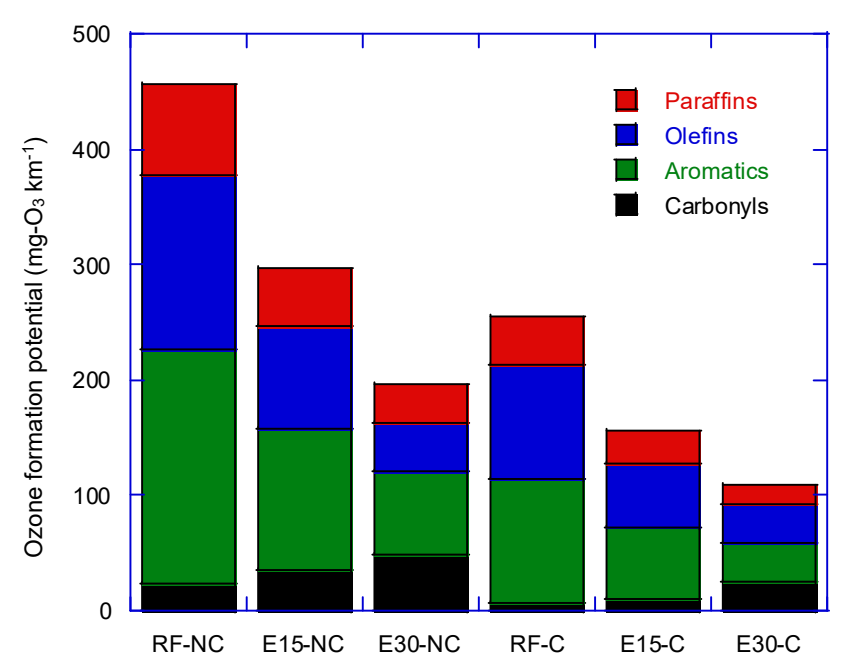

Fig. 5. Ozone formation potential of VOCs for regulated gasoline (RF), E15 and E30 associated with non-catalyst (NC) and catalyst (C).

were much less than that of regulated gasoline. The ethanol additive gasoline is not easy to promotion due to its sources of raw materials (most of ethanol is import from othercountries), high cost, fuel consumption, and corrosion of engine system. The government has to set up the longterm targets for the bio-ethanol development and emission reduction and integrated design a set of interrelated research, technology, development and innovation policies for the bio-ethanol application system (Chung and Yang, 2016) to enhance the growth of ethanol alternative fuels in Taiwan.

\section{CONCLUSIONS}

Using ethanol-blended fuel can significantly reduce $\mathrm{CO}$ emissions (by 30-37\%) and $\mathrm{HC}$ emissions (by 19-28\%) compared to using regulated gasoline, and adding a catalyst to the tailpipe exhaust system can decrease $\mathrm{CO}, \mathrm{HC}$, and $\mathrm{NO}_{x}$ emissions by $12-60 \%, 32-39 \%$, and $81-85 \%$, respectively, for various fuels. The results of this study showed that the specific surface areas for catalyst-5000 and catalyst-10700 were approximately $50 \%$ less than those for brand new catalysts. After the test engines reached a mileage of 16,000 $\mathrm{km}$, the specific surface areas decreased to about one third of those of a new catalyst. Additionally, after the increase in mileage, the catalysts exhibited reduced quantities of three catalytic noble metals ( $\mathrm{Rh}, \mathrm{Pd}$, and $\mathrm{Pt}$ ) and increased quantities of $\mathrm{P}$ and $\mathrm{S}$.

Adding ethanol to the gasoline decreased paraffin, olefin, and aromatic emissions but increased carbonyl emissions. The VOCs in the tailpipe exhaust consisted of $49-52 \%$ paraffins, $9.5-14 \%$ olefins, $26-30 \%$ aromatics, and $4.5-16 \%$ carbonyls. When the exhaust was treated with a catalytic system, the ozone formation potential of the analyzed VOCs decreased from 457 to $256 \mathrm{mg}-\mathrm{O}_{3} \mathrm{~km}^{-1}$ for regulated gasoline, 298 to $156 \mathrm{mg}-\mathrm{O}_{3} \mathrm{~km}^{-1}$ for $\mathrm{E} 15$, and 196 to $109 \mathrm{mg}-\mathrm{O}_{3} \mathrm{~km}^{-1}$ for E30. However, the VOC ozone formation potential of an aged catalyst $(16,200 \mathrm{~km})$ was $1.59-1.77$ times higher than that of a brand new catalyst. 

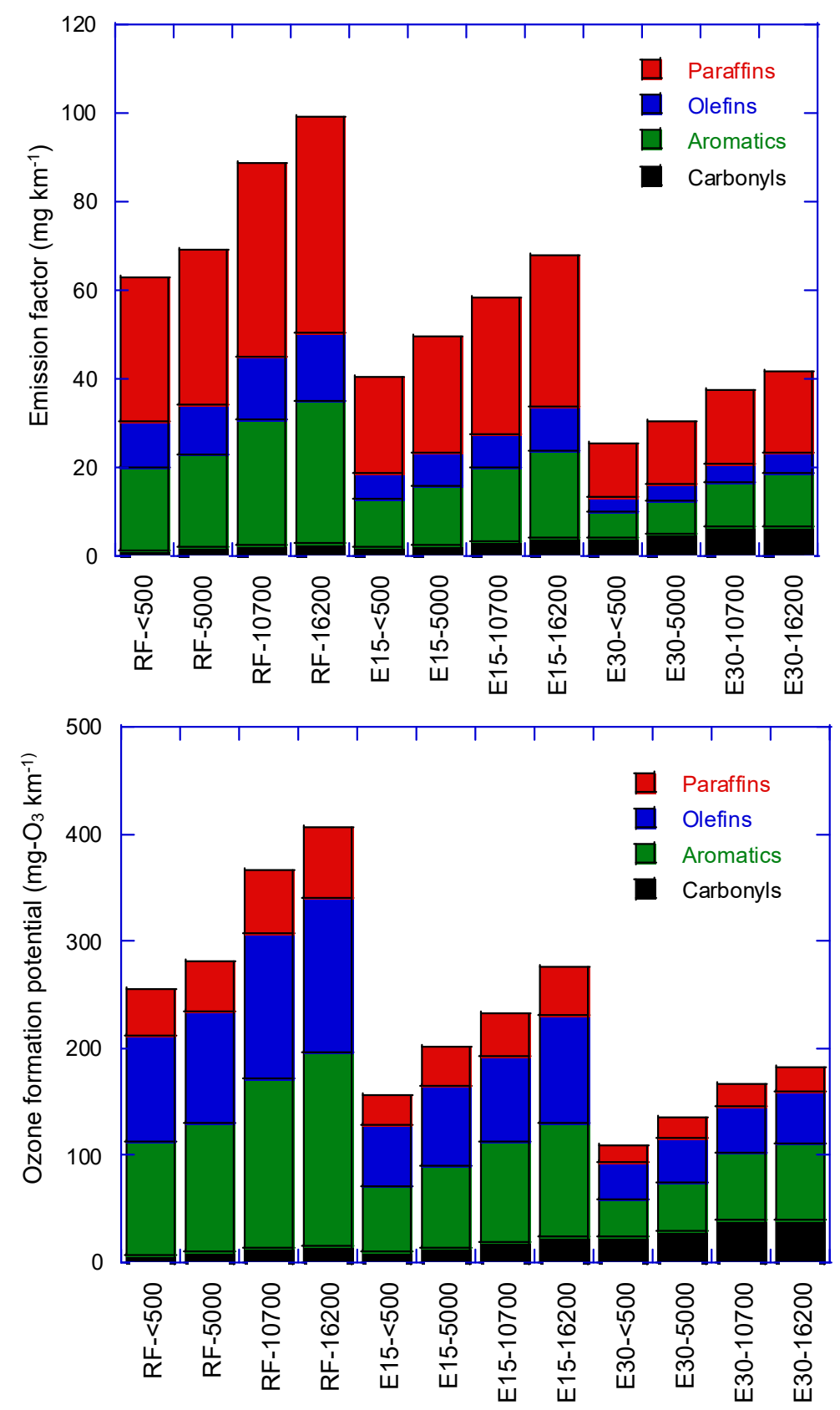

Fig. 6. VOCs emission factors and ozone formation potentials for regulated gasoline, E15 and E30 associated with catalyst aging (mileage $<500,5000,10700$ and $16200 \mathrm{~km}$ ).

\section{ACKNOWLEDGEMENTS}

The authors express their sincere thanks to the Ministry of Science and Technology, Republic of China (Taiwan), for research fund support (MOST 98-2221-E-006-024-MY3, MOST 101-2221-E-006-160-MY3, and MOST 104-2221E-006-020-MY3).

\section{REFERENCES}

Acuña, L.M., Fuentes, R.O., Fantini, M.C.A. and Lamas, D.G. (2014). Relation between distortions in the oxygen sublattice and the local order of $\mathrm{Zr}$ in nanostructured
$\mathrm{ZrO}_{2}-\mathrm{CeO}_{2}$ mixed oxides. J. Phys. Chem. C 118: $11445-$ 11453.

Agarwal, A.K. (2007). Biofuels (alcohols and biodiesel) applications as fuels for internal combustion engines. Prog. Energy Combust. Sci. 33: 233-271.

Alla, S.K., Devarakonda, K.K., Komarala, E.V.P., Mandal, R.K. and Prasad, N.K. (2017). Ferromagnetic Fe-substituted cerium oxide nanorods: Synthesis and characterization. Mater. Des. 114: 584-590.

Alves, C.A., Barbosa, C., Rocha, S., Calvo, A., Nunes, T., Cerqueira, M., Pio, C., Karanasiou, A. and Querol, X. (2015). Elements and polycyclic aromatic hydrocarbons in exhaust particles emitted by light-duty vehicles, 
Environ. Sci. Pollut. Res. 22: 11526-11542, doi: 10.1007/s11356-015-4394-x.

Alvim, D.S., Gatti, L.V., Corrêa, S.M., Chiquetto, J.B., Santos, G.M., Rossatti, C. de S., Pretto A., Rozante, J.R., Figueroa, S. N., Pendharkar, J. and Nobre P. (2018). Determining VOCs reactivity for ozone forming potential in the megacity of São Paulo. Aerosol Air Qual. Res. 18: 2460-2474.

Bergthorson, J.M. and Thomson, M.J. (2015). A review of the combustion and emissions properties of advanced transportation biofuels and their impact on existing and future engines. Renewable Sustainable Energy Rev. 42: 1393-1417.

Bumajdad, A., Zaki, M.I., Eastoe, J. and Pasupulety, L. (2006). Characterization of nano-cerias synthesized in microemulsions by $\mathrm{N}_{2}$ sorptiometry and electron microscopy. J. Colloid Interface Sci. 302: 501-508.

Carter, W.P.L. (2009). Updated maximum incremental reactivity scale and hydrocarbon bin reactivities for regulatory applications. Prepared for California Air Resources Board Contract 07-339. University of California, Riverside.

Chernyshev, V.V., Zakharenko, A.M., Ugay, S.M., Hien, T.T., Hai, L.H., Kholodov, A.S., Burykina, T.I., Stratidakis, A.K., Mezhuev, Y.O., Tsatsakis, A.M. and Golokhvast, K.S. (2018). Morphologic and chemical composition of particulate matter in motorcycle engine exhaust. Toxicol. Rep. 5: 224-230. doi: 10.1016/J.TOXREP. 2018.01.003.

Chiang, H.L., Huang, P.H., Lai, Y.M. and Lee, T.Y. (2014). Comparison of the regulated air pollutant emission characteristics of real-world driving cycle and ECE cycle for motorcycles. Atmos. Environ. 87: 1-9. doi: 10.1016/j.atmosenv.2013.12.031.

Chung, C.C. and Yang, S.C. (2016). The emergence and challenging growth of the bio-ethanol innovation system in Taiwan (1949-2015). Int. J. Environ. Res. Public Health 13: 230; doi: 10.3390/ijerph13020230.

Clairotte, M., Adam, T.W., Zardini, A.A., Manfredi, U., Martini, G., Krasenbrink, A., Vicet, A., Tournie, E. and Astorga, C. (2013). Effects of low temperature on the cold start gaseous emissions from light duty vehicles fuelled by ethanol-blended gasoline. Appl. Energy 102: 44-54.

Costagliola, M.A., Murena, F. and Prati, M.V. (2014). Exhaust emissions of volatile organic compounds of powered two-wheelers: effect of cold start and vehicle speed. Contribution to greenhouse effect and tropospheric ozone formation, Sci. Total Environ. 468-469: 10431049, doi: 10.1016/J.SCITOTENV. 2013.09.025.

Costagliola, M.A., Prati, M.V. and Murena, F. (2016). Bioethanol/gasoline blends for fuelling conventional and hybrid scooter: Regulated and unregulated exhaust emissions. Atmos. Environ. 132: 133-140, doi: 10.1016/j.atmosenv.2016.02.045.

de Assis Brasil Weber, N., da Rocha, B.P., Smith Schneider, P., Daemme, L.C. and de Arruda Penteado Neto, R. (2019). Energy and emission impacts of liquid fueled engines compared to electric motors for small size motorcycles based on the Brazilian scenario. Energy 168: 70-79. de Melo, T.C.C., Machado, G.B., Belchior, C.R.P., Colaço, M.J., Barros, J.E.M., de Oliveira, E.J. and de Oliveira, D.G. (2012). Hydrous ethanol-gasoline blends Combustion and emission investigations on a Flex-Fuel engine. Fuel 97: 796-804.

DeMarini, D.M., Brooks, L.R., Warren, S.H., Kobayashi, T., Gilmour, M.I. and Singh, P. (2004). Bioassay-directed fractionation and Salmonella mutagenicity of automobile and forklift diesel exhaust particles. Environ. Health Perspect. 112: 814-819, doi: 10.1289/ehp.6578.

Deng, C., Jin, Y., Zhang, M., Liu, Xi. and Yu, Z. (2018). Emission characteristics of VOCs from on-road vehicles in an urban tunnel in eastern china and predictions for 2017-2026. Aerosol Air Qual. Res. 18: 3025-3034.

Durant, J.L., Busby, W.F., Lafleur, A.L., Penman, B.W. and Crespi, C.L. (1996) Human cell mutagenicity of oxygenated, nitrated and unsubstituted polycyclic aromatic hydrocarbons associated with urban aerosols. Mutat. Res. Genet. Toxicol. 371: 123-157, doi: 10.1016/S01651218(96)90103-2.

Durant, J.L., Lafleur, A.L., Busby, W.F., Donhoffner, L.L., Penman, B.W. and Crespi, C.L. (1999). Mutagenicity of C24H14 PAH in human cells expressing CYP1A1. Mutat. Res. Genet. Toxicol. Environ. Mutagen. 446: 1-14, doi: 10.1016/S1383-5718(99)00135-7.

Fernández-García, M., Martínez-Arias, A., Guerrero-Ruiz, A., Conesa, J.C. and Soria, J. (2002). Ce-Zr-Ca ternary mixed oxides: structural characteristics and oxygen handling properties. J. Catal. 211: 326-334.

Hoang, A.T., Tran, Q.V., Al-Tawaha, A.R.M.S., Pham, V.V. and Nguyen, X.P. (2019). Comparative analysis on performance and emission characteristics of an inVietnam popular 4-stroke motorcycle engine running on biogasoline and mineral gasoline. Renew Energy Focus 28: 47-55.

Hua, X., Wu, Y.J., Zhang, X., Cheng, S., Wang, X., Chu, J. and Huang, Q. (2018). Analysis on ambient volatile organic compounds and their human gene targets. Aerosol Air Qual. Res. 18: 2654-2665.

Jia, C., Wang, Y., Li, Y., Huang, T., Mao, X., Mo, J., Li, J., Jiang, W., Liang, X., Gao, H. and Ma, J. (2018). Oxidative capacity and radical chemistry in a semi-arid and petrochemical-industrialized city, northwest China. Aerosol Air Qual. Res. 18: 1391-1404.

Johnson, D.W. (2016). The tribology and chemistry of phosphorus-containing lubricant additives. In Advances in tribology, Darji, P.H. (Ed.), IntechOpen, doi: 10.5772/63654.

Kašpar, J., Fornasiero, P. and Hickey, N. (2003). Automotive catalytic converters: Current status and some perspectives. Catal. Today 77: 419-449.

Kim, H., Choi, W.C., Rhee, H.J., Suh, I., Lee, M., Blake, D.R., Kim, S., Jung, J., Lee, G., Kim, D.S., Park, S.M., Ahn, J., Lee, S.D. (2018). Meteorological and chemical factors controlling ozone formation in Seoul during MAPS-Seoul 2015. Aerosol Air Qual. Res. 18: 22742286.

Lan, L., Chen, S., Zhao, M., Gong, M. and Chen, Y. (2014). The effect of synthesis method on the properties and 
catalytic performance of $\mathrm{Pd} / \mathrm{Ce}_{0.5} \mathrm{Zr}_{0.5} \mathrm{O}_{2}-\mathrm{Al}_{2} \mathrm{O}_{3}$ three-way catalyst. J. Mol. Catal. A Chem. 394 :10-21.

Larsen, U., Johansen, T. and Schramm, J. (2009). Ethanol as a Fuel for Road Transportation. Main Report. IEA-AMF report 100.

Li, G., Wang, Q., Zhao, B. and Zhou, R. (2010). The promotional effect of transition metals on the catalytic behavior of model $\mathrm{Pd} / \mathrm{Ce}_{0.67} \mathrm{Zr}_{0.33} \mathrm{O}_{2}$ three-way catalyst. Catal. Today 158: 385-392.

Lim, C.S., Lim, J.H., Cha, J.S. and Lim, J.Y. (2019). Comparative effects of oxygenates-gasoline blended fuels on the exhaust emissions in gasoline-powered vehicles. $J$. Environ. Manage. 239: 103-113

Lin, Y.C., Chou, F.C., Li, Y.C., Jhang, S.R. and Shangdiar, S. (2019). Effect of air pollutants and toxic emissions from various mileage of motorcycles and aerosol related carcinogenicity and mutagenicity assessment. J. Hazard Mater. 365:771-777

Meng, L. (2019). Chapter 11 - Ethanol in Automotive Applications. In Ethanol, Basile, A., Iulianelli, A., Dalena, F. and Veziroğlu, T.N. (Eds.), Elsevier, pp. 289303. doi: 10.1016/B978-0-12-811458-2.00011-0.

Monte, R.D. and Kašpar, J. (2005). Heterogeneous environmental catalysis - A gentle art: $\mathrm{CeO}_{2}-\mathrm{ZrO}_{2}$ mixed oxides as a case history. Catal. Today 100: 27-35.

Najafi, G., Ghobadian, B., Tavakoli, T., Buttsworth, D.R., Yusaf, T.F. and Faizollahnejad, M. (2009). Performance and exhaust emissions of a gasoline engine with ethanol blended gasoline fuels using artificial neural network. Appl. Energy 86: 630-639.

Piumetti, M., Bensaid, S., Fino, D. and Russo, N. (2016). Nanostructured ceria-zirconia catalysts for CO oxidation: study on surface properties and reactivity. Appl. Catal. B 197: 35-46.

Ramanathan, K. and Sharma, C.S. (2011). Kinetic parameters estimation for three way catalyst modeling. Ind. Eng. Chem. Res. 50: 9960-9979.

Rodriguez-Anton, L.M., Gutierrez-Martin, F. and MartinezArevalo, C. (2015). Experimental determination of some physical properties of gasoline, ethanol and ETBE ternary blends. Fuel 156: 81-86.

Russell, A.G., Milford, J.B., Bergin, M.S., McBride, S., McNair, L., Yang, Y., Stockwell, W. and Croes, B.E. (1995). Urban ozone control and atmospheric reactivity of organic gases. Science 269:491-495.

Sakthivela, P., Subramanian K.A. and Mathai, R. (2019). Comparative studies on combustion, performance and emission characteristics of a two-wheeler with gasoline and $30 \%$ ethanol-gasoline blend using chassis dynamometer. Appl. Therm. Eng. 146: 726-737.

Sarkar, C., Chatterjee, A., Majumdar, D., Roy, A., Srivastava, A., Ghosh, S.K. and Raha, S. (2017). How the atmosphere over eastern Himalaya, India is polluted with carbonyl compounds? Temporal variability and identification of sources. Aerosol Air Qual. Res. 17: 2206-2223.

Shelef, M. and Graham, G.W. (1994). Why Rhodium in Automotive Three-Way Catalysts? Catal. Rev. Sci. Eng. 36: $433-457$
Sun, S.D., Jiang, W. and Gao, W.D. (2016). Vehicle emission trends and spatial distribution in Shandong province, China, from 2000 to 2014, Atmos. Environ. 147:190-199.

Swatsitang, E., Phokha, S., Hunpratub, S. and Maensiri, S. (2016). Modification of Ce valence states by $\mathrm{Sm} / \mathrm{Sr}$ codoping of $\mathrm{CeO}_{2}$ nanoparticles for improved magnetoelectrochemical properties. Mater. Des. 108: 27-33.

Tan, N.I., Ahmad, R., Ansari, H.M., Zain, N.M., Akbar, S.A. and Pingguan-Murphy, B. (2016). Human fetal osteoblast cell response to self-assembled nanostructures on YSZ(110) single crystal substrates. Mater. Des. 94: 274-279.

Tan, W., Deng, J., Xie, S., Yang, H., Jiang, Y., Guo, G. and Dai, H. (2015). $\mathrm{Ce}_{0.6} \mathrm{Zr}_{0.3} \mathrm{Y}_{0.1} \mathrm{O}_{2}$ nanorod supported gold and palladium alloy nanoparticles: High-performance catalysts for toluene oxidation. Nano 7: 8510-8523.

Taylor, A.B., Moran, D.P., Bell, A.J., Hodgson, N.G., Myburgh, I.S. and Botha, J.J. (1996). Gasoline/alcohol blends: Exhaust emission, performance and Burn-rate in multi-valve production engine. SAE paper no. 961988.

Tsai, J.H., Yao, Y.C., Huang, P.H. and Chiang, H.L. (2017). Criteria pollutants and volatile organic compounds emitted from motorcycle exhaust under various regulation phases. Aerosol Air Qual. Res. 17: 1214-1223.

Tsai, J.H., Yao, Y.C., Huang, P.H. and Chiang, H.L. (2018). Fuel economy and volatile organic compound exhaust emission for motorcycles with various running mileages. Aerosol Air Qual. Res. 18: 3056-3067.

U.S. Energy Information Administration (U.S EIA). (2016b). Almost all U.S. gasoline is blended with $10 \%$ ethanol. Today in Energy. U.S. Department of Energy, United States.

U.S. Energy Information Administration (U.S. EIA) (2016a). International energy outlook 2016, U.S. Energy Information Administration, May 2016, https://www.eia.gov/outlook s/ieo/pdf/0484(2016).pdf, Last Access: 24 May 2019.

United States Environmental Protection Agency (U.S. EPA) (2019). Fast Facts: U.S. Transportation Sector GHG Emissions, https:/www.epa.gov/greenvehicles/fast-factstransportation-greenhouse-gas-emissions, Last Access: October, 2019.

Vasic, A.M. and Weilenmann, M. (2006). Comparison of real-world emissions from two wheelers and passenger cars, Environ. Sci. Technol. 40:149-154.

Weiss, M., Dekker, P., Moro, A., Scholz, H. and Patel, M.K. (2015). On the electrification of road transportation a review of the environmental, economic, and social performance of electric two-wheelers. Transp. Res. D 41: 348-366.

Widiana, D.R., You, S.J., Yang, H.H., Tsai, J.H. and Wang, Y.F. (2017). Source apportionment of air pollution and characteristics of volatile organic compounds in a municipal wastewater treatment plant, north Taiwan. Aerosol Air Qual. Res. 17: 2878-2890.

Yao, Y.C., Tsai, J.H., Wang, I.T. and Tsai, H.R. (2017). Investigating criteria and organic air pollutant emissions from motorcycles by using various ethanol-gasoline blends. Aerosol Air Qual. Res. 17: 167-175.

Yusoff, M.N.A.M., Zulkifli, N.W.M., Masjuki, H.H., Harith, 
M.H., Syahir, A.Z., Khuong, L.S., Zaharin, M.S.M. and Alabdulkarem, A. (2018). Comparative assessment of ethanol and isobutanol addition in gasoline on engine performance and exhaust emissions. J. Cleaner Prod. 190: 483-495.
Received for review, October 26, 2019

Revised, November 14, 2019

Accepted, November 15, 2019 